DOI: https://doi.org/10.31933/jemsi.v3i2 Received: 20 Oktober 2021, Revised: 15 November 2021, Publish: 6 Desember 2021

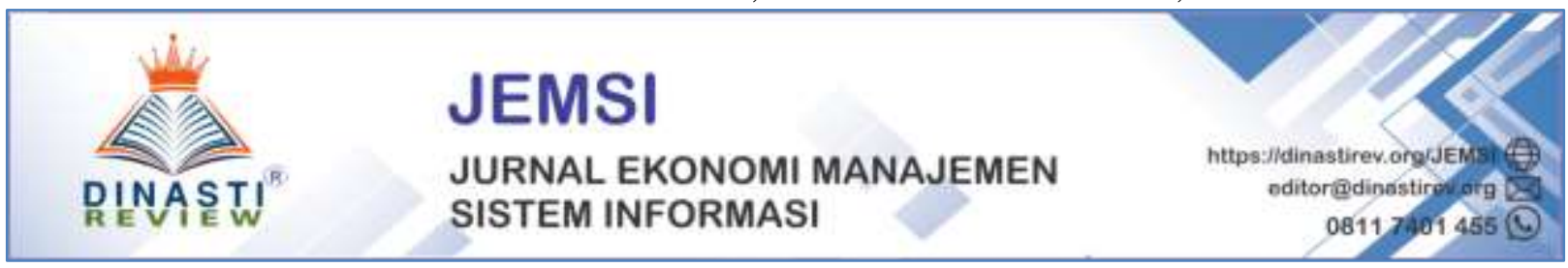

\title{
SUPERVISI PENGAJARAN DALAM PERSEPSI TENAGA PENDIDIK: SEBUAH STUDI DI PONDOK MODERN DARUSSALAM GONTOR KAMPUS 10 TANJABTIM JAMBI
}

\author{
Moh. Ikrom Mubarok ${ }^{1}$, Sudarso Sudarso ${ }^{2}$, Suryawahyuni Latief ${ }^{3}$ \\ ${ }^{1}$ Postgraduate Students UIN Sultan Thaha Saifuddin Jambi, Email: barok679@ gmail.com \\ ${ }^{2}$ Postgraduate Students UIN Sultan Thaha Saifuddin Jambi, Email: sudarsoindo@ gmail.com \\ ${ }^{3}$ Nurdin Hamzah University, Email: niniek_yuni@yahoo.com
}

\section{Corresponding Author: Moh. Ikrom Mubarok}

\begin{abstract}
Abstrak: Pendidikan merupakan salah satu kewajiban yang harus ditempuh oleh setiap anak bangsa, agar dimasa yang akan datang dapat bersaing dan tidak tertinggal oleh bangsa lain. Guru sebagai kunci dalam keberhasilan pendidikan yang ditempuh oleh anak didik. Maka, figur guru sebagai garda terdepan dalam mencerdaskan anak didiknya perlu dibimbing dan dibina melalui supervisi pengajaran agar keberhasilan penyelenggaraan pendidikan dapat meningkat. Akan tetapi, hal ini malah menimbulkan beberapa persepsi guru terhadap kegiatan supervisi pengajaran. Oleh karena itu, tujuan penelitian ini adalah menguraikan bagaimana persepsi guru terhadap kegiatan supervisi pengajaran khususnya di Pondok Modern Darussalam Gontor kampus 10 Jambi. Informan dalam penelitian ini adalah guru di Pondok Modern Darussalam Gontor kampus 10 Jambi. Penelitian ini menggunakan pendekatan kualitatif dengan metode deskriptif. Hasil penelitian menunjukkan bahwa persepsi guru tentang supervisi pengajaran meliputi kesiapan guru dalam menjalankan tugasnya, penguasaan materi, cara penyampaian, dan disiplin guru itu sendiri.
\end{abstract}

Kata Kunci: Supervisi Pengajaran, Persepsi, Pendidikan

\section{PENDAHULUAN}

Dewasa ini sangat sering kita jumpai dari beragam sumber baik media cetak maupun televisi yang mengangkat tema atau isu tentang problematika pendidikan yang ada di Indonesia, tidak jarang pula memunculkan perdebatan dikalangan akademisi, pemerintah maupun masyarakat. Keprihatinan akan ketimpangan mutu dan kualitas pendidikan yang ada dipusat, daerah, dan pelosok negri ini seharusnya menjadi fokus perhatian pemerintah, agar target yang dicanangkan pemerintah dapat tercapai terutama pada standarisasi mutu pendidikan. Maka diera globalisasi seperti saat ini, pendidikan merupakan salah satu kewajiban yang harus ditempuh baik personal maupun sosial dan ini tidak bisa ditawar-tawar lagi. Karena pada dasarnya pendidikan 
adalah merupakan proses sosial yang bertujuan untuk mengembangkan potensi manusia demi menghadapi perkembangan dan perubahan zaman, dimana tatanan sosial juga ikut bergeser.

Perlu kita ketahui Bersama bahwasannya penyelenggaraan pendidikan nasional adalah realisasi dari amanat Pembukaan UUD 1945 yaitu mencerdaskan kehidupan bangsa. Maka disebutkan didalam pasal 31 ayat (1) Setiap warga negara berhak mendapat pendidikan, (2) Setiap warga negara wajib mengikuti pendidikan dasar dan pemerintah wajib membiayainya, (3) Pemerintah mengusahakan dan menyelenggarakan satu sistem pendidikan nasional, yang meningkatkan keamanan dan ketaqwaan serta akhlak mulia dalam rangka mencerdaskan kehidupan bangsa, yang diatur dengan undang-undang, (4) Negara memprioritaskan anggaran pendidikan sekurang-kurangnya dua puluh persen dari anggaran pendapatan dan belanja negara serta dari anggaran pendapatan dan belanja daerah untuk memenuhi kebutuhan penyelenggaraan pendidikan nasional, dan (5) Pemerintah memajukan ilmu pengetahuan dan teknologi dengan menjunjung tinggi nilai-nilai agama dan persatuan bangsa untuk kemajuan peradaban serta kesejahteraan umat manusia. Ini berarti menunjukkan komitmen pemerintah dalam menyelenggarakan pendidikan nasional bagi seluruh bangsa Indonesia tanpa terkecuali. Disamping itu, dalam Undang-Undang Nomor 20 Tahun 2003 tentang Sistem Pendidikan Nasional ditegaskan bahwa jalur pendidikan terdiri atas pendidikan formal, nonformal, dan informal yang dapat saling melengkapi dan memperkaya (Pasal 13 ayat 1). Jenjang pendidikan formal terdiri atas pendidikan dasar, pendidikan menengah, dan pendidikan tinggi.

Ini menandakan begitu pentingnya meningkatkan mutu pendidikan, agar calon generasi penerus bangsa nantinya dapat bersaing di tingkat nasional maupun international. Keurgensian dari pendidikan itu sendiri selalu ditandai dengan perkembangan ilmu pengetahuan dan teknologi (IPTEK) yang memberi motivasi serta dorongan pelaksanaan dan tanggugjawab guru pada umumnya, khususnya pada supervisor untuk meningkatkan mutu pendidikan. Akan tetapi tidak jarang cibiran tertuju pada seorang supervisor dalam melaksanakan tugas pokok dan fungsinya. Maka profesonalisme dan fungsionalisme lalu tampil sebagai suatu kebutuhan yang utama dalam keperluan pelaksanaan pendidikan pada semua tingkatan sekolah. Sebagaimana halnya dalam kenyataannya dewasa ini bahwa kebutuhan masyarakan terhadap pendidikan formal yang sangat terbatas kemampuan pelayanannya di mana tentunya tidak hanya kualitasnya, akan tetapi justru telah memacu pada peningkatan kualitas pendidikan. Dengan demikian supervisor merupakan komponen yang memiliki peranan tanggungjawab yang cukup besar dalam meningkatkan mutu pendidikan, yang pada umumnya berkewajiban untuk mengarahkan, mengawasi, dan mengevaluasi capaian-capaian kualitas pendidikan khususnya pada Sekolah Dasar. Tindakan supervisi diperlukan guna meningkatkan dan memperbaiki bagaimana berjalannya proses belajar mengajar yang dilakukan oleh seorang guru atau tenaga pendidik.

Akan tetapi muncul sebuah permasalahan dimana output pendidikan yang dihasilkan rendah, yang secara umum pastinya merujuk pada lemahnya pelaksanaan supervisi yang dilakukan di sekolah-sekolah. Secara garis besar kita dapat menilai bilamana sebuah Lembaga pendidikan menghasilkan output yang baik tentunya dapat kita pastikan proses belajar mengajarnya juga baik, juga dari segi supervisi yang telah dilakukan, sebagaimana yang tertuang dalam ketentuan- 
ketentuan dan juga tujuan pendidikan. Karena supervisi memang bertujuan untuk membantu guru dalam meningkatkan dan memperbaiki pelayanan terhadap peserta didik. Namun tidak semua kepala sekolah didalam sebuah Lembaga pendidikan telah melaksanakan supervisi dengan baik dan benar, juga sikap guru terhadap jalannya proses supervisi ikut memberikan andil mengapa supervisi tidak berjalan sebagaimana mestinya.

Akan tetapi dari adanya kegiatan supervisi pengajaran sikap guru pun bervariatif dalam menanggapinya, ada yang menerima dengan senang hati manakala disupervisi adapula yang menanggapinya secara negative ada juga yang menganggap itu hal biasa. Persepsi guru tentang adanya supervisi tersebut sebenarnya mencerminkan pola pikir dari seorang guru tadi, jika memanggapi secara positif, maka guru itu memang terbuka untuk ditingkatkan dan dievaluasi karena menyadari akan kekurangan dirinya dalam mengajar dan mendidik siswa. Dan yang bersikap negatif merasa bahwasannya supervisi pengajaran merupakan model pengawasan terhadap seorang guru yang mana akhirnya guru tidak bebas dalam mengajar kan materi pelajaran terhadap siswa karena sedang diawasi, dan dicari-cari kesalahan. Kemudian yang bersikap supervisi adalah hal yang biasa karena memang itu adalah tugas seorang supervisor.

Dari uraian diatas dapat disimpulkan bahwa penelitian tentang supervisi pengajaran dalam persepsi tenaga pendidik di Madrasah dirasa penting dan menarik untuk dikaji, Idealnya seorang guru harus memiliki kompetensi yang baik seperti yang telah tertuang dalam tujuan utama pendidikan, yang mana jika seaidainya seorang guru tidak memiliki kompetensi yang mumpuni didalam mendidik maka dapat dipastikan output yang dihasilkan oleh siswa juga tidak jauh berbeda dengan kemampuan guru tadi, begitu juga pada petugas yang diamanahi jabatan untuk menjadi supervisor, harus betul-betul menguasai apa yang menjadi tugas dan tanggung jawabnya sehingga berdampak baik terhadap guru yang disupervisi.

akan tetapi pada kenyataannya di lapangan yang terjadi adalah masih banyak terdapat guru yang pola sikap, perilaku dan persepsinya terhadap kegiatan supervisi belum menunjukkan tandatanda kearah kebaikan. Karena itulah perlu adanya bimbingan dan pembiasaan terhadap para guru agar lebih faham maksud dan tujuan dari kegiatan supervisi. Hal ini menjadi lebih urgent lagi manakala menyangkut masalah kualitas dan mutu pendidikan yang nantinya menyangkut masa depan pribadi siswa dan juga bangsa. Maka tujuan diadakannya penelitian ini untuk mendeskripsikan tentang supervisi pengajaran dan juga bagaimana sikap guru atau tenaga pendidik terhadap kegiatan supervisi pengajaran khususnya di Pondok Modern Darussalam Gontor Kampus 10 Jambi. Maka tujuan penelitian ini adalah untuk menguraikan bagaimana persepsi tenaga pendidik di Pondok Modern Darussalam Gontor Kampus 10 Jambi dalam supervise pengajaran.

\section{KAJIAN PUSTAKA}

Dalam kehidupan dipesantren murid/santri adalah sebuah amanah yang sangat besar, oleh karena itu para Kyai, guru dan pengurus menaruh perhatian yang sangat serius dalam mengembangkan mental dan karakter para santri. Mereka diajarkan untuk selalu menjalankan kewajiban dan tanggung jawab sehingga kelak dapat menyalurkan ilmu ke masyarakatnya, sehingga ajaran Islam akan senantiasa berkembang. Menurut (Amin, 2016) Pondok pesantren 
adalah lembaga yang bergerak dalam bidang pendidikan, maka seluruh apa yang di ajarkan di dalamnya harus bersifat kompehensif. Pendidikan dan pengajaran yang sifatnya akademis harus mendapatkan porsi yang sama, dengan tujuan agar para santri dapat hidup dan berkiprah dimasyarakat sesuai dengan perkembangan zaman. Itulah kenapa Pondok Modern Darussalam Gontor selalu totalitas didalam mendidik para santri-santrinya. Para guru selalu berusaha untuk menjadi teladan yang baik bagi seluruh santri terkhusus dalam proses belajar mengajar. Keteladanan guru menurut (Syaepul Manan, 2017) ini tidak kalah pentingnya dengan proses belajar mengajar di dalam kelas, hal ini disebabkan proses pengetahuan atau tingkah laku yang diperoleh dari pembiasaan akan sangat sulit untuk mengubah dan menghilangkannya, maka dari itu keteladanan yang baik akan sangat berpengaruh pada pola pikir dan tingkah laku anak dikemudian hari.

Jika kita merujuk pada istilah jawa seorang guru itu "di gugu lan di tiru" maka seluruh tindakan, perkataan dan tingkah laku seorang guru pastinya menjadi sorotan seluruh siswanya, apalagi didalam proses belajar mengajar, seorang guru dituntut untuk tidak boleh salah, apalagi didalam menyampaikan materi pelajaran, maka seorang guru harus memiliki kompetensikompetensi profesional. Seperti yang disampaikan (Djailani, 2012) seorang guru harus memiliki kompetensi pedagogik, kompetensi kepribadian, kompetensi profesional, kompetensi sosial didalam dirinya sehingga betul-betul tidak hanya penyampai materi pelajaran, akan tetapi dapat menjadi pendidik yang baik tanpa cacat. Ini sejalan denga napa yang disampaikan (Burhanuddin, 2017) dalam tulisannya bahwa kebijakan pendidikan harus ditopang oleh pelaku pendidikan yang berada di front terdepan, yakni seorang guru yang melalui interaksinya didalam pendidikan. Maka usaha dalam meningkatkan mutu pendidikan yang berkualitas perlu di kaji secara menyeluruh dan komprehensif, yang salah satunya adalah peningkatan keprofesionalan guru melalui kegiatan supervisi pengajaran.

Dalam tulisannya (Aedi, 2014) menjelaskan bahwa supervisi berasal dari dua kata yaitu "super" dan "vision". Kata "super mengandung makna peringkat atau posisi yang lebih tinggi, superior, atasan, lebih hebat atau lebih baik. Sedangkan kata "vision" berarti mengandung makna kemampuan untuk menyadari sesuatu tidak benar-benar terlihat. Sedangkan menurut (Rugaiyah, 2016) kegiatan supervisi adalah upaya memperbaiki dan mengontrol segala aktivitas agar terlakasana secara optimal. Ini bertujuan untuk memastikan kegiatan secara efektif dilaksanakan oleh mereka yang bertanggung jawab untuk melakukannya. (Supriadi, 2019) Hakikat supervisi dalam pendidikan Islam adalah upaya bersama yang dilakukan untuk memperbaiki kualitas belajar dan pembelajaran dengan prinsip ilmiah dan kerjasama. Praktik supervisi yang dilakukan dengan baik dan kontiniu, berpengaruh secara signifikan terhadap perubahan pendidikan ke arah yang lebih baik. Yang mana tujuan nya paling tidak ikut berkontribusi dalam memperbaiki pendidikan (paling tidak dari sisi kinerja guru dan proses pembelajaran). Ditinjau dari segi pendidikan menurut (Niswanto., 2016) supervisi diartikan dengan prosedur memberi arah serta mengadakan penilaian secara kritis terhadap proses pengajaran. Sedangkan (Ubabuddin, 2019) dalam tulisannya 
menjelaskan bahwa Supervisi merupakan usaha pejabat sekolah dalam memimpin guru-guru dan tenaga kependidikan lainnya, untuk memperbaiki pengajaran termasuk menstimulasi, menyeleksi pertumbuhan dan perkembangan jabatan guru-guru, menyeleksi dan merevisi tujuan-tujuan pendidikan, bahan pengajaran, dan metode-metode mengajar serta evaluasi pengajaran. Jadi dari penjelasan para ahli mengenai makna dari supervisi dapat diambil kesimpulan bahwa supervisi merupakan sebuah usaha yang dilakukan oleh supervisor untuk meningkatkan dan mengembangkan guru melalui pengawasan dan evaluasi baik didalam maupun luar kelas, yang mana diharapkan setelah adanya supervisi kualitas guru dan mutu pendidikan dapat meningkat.

Supervisi pengajaran menurut (Gunawan, 2015) adalah layanan yang diberikan supervisor kepada guru, dengan tujuan memperbaiki kualitas pembelajaran. Sedangkan menurut (Maya putri, 2016) Supervisi pengajaran adalah upaya untuk meningkatkan kualitas proses belajar mengajar sehingga dapat memperbaiki dan mengembangkan kualifikasi professional para guru. (Budiman et al., 2015) Menjelaskan bahwa supervisi pendidikan merupakan upaya seorang kepala sekolah dalam pembinaan guru agar dapat meningkatkan kualitas mengajarnya dengan melalui langkahlangkah perencanaan, pelaksanaan, dan tindak lanjut. Sedangkan tujuan dan manfaat diadakannya supervisi pengajaran menurut (Aedi, 2014) adalah (1) membina guru untuk lebih memahami tujuan pendidikan; (2) melatih kesanggupan guru untuk mempersiapkan peserta didiknya menjadi anggota masyarakat yang efektif; (3) membantu guru untuk mengadakan diagnosis; (4) meningkatkan kesadaran terhadap tata kerja demokratis; (5) memperbesar ambisi guru untuk meningkatkan mutu kerjanya secara maksimal; (6) membantu mempopulerkan sekolah ke masyarakat; (7) membantu guru untuk lebih dapat memanfaatkan pengalamannya sendiri; (8) mengembangkan persatuan antar guru; dan (9) membantu guru untuk dapat mengevaluasi aktivitasnya dalam kontak tujuan perkembangan peserta didik. Sedangkan menurut (Suklani \& Wahyudi, 2012) tujuan supervisi pendidikan adalah meningkatkan kemampuan profesional dan teknis bagi guru, Kepala Sekolah, dan personal sekolah lainnya agar proses pendidikan di sekolah lebih berkualitas, dan yang utama supervisi pendidikan atas dasar kerja sama, partisipasi, dan kolaborasi, bukan berdasarkan paksaan dan kepatuhan. Dengan demikian, akan timbul kesadaran, inisiatif, dan kreatif personal sekolah. Dari penjelasan diatas maka seorang supervisor peranannya sangat besar dalam peningkatan guru dan mutu pendidikan, itulah mengapa seorang supervisor harus memiliki kemampuan profesional yang handal. Seorang gurupun juga harus dapat memahami peran dan fungsi seorang supervisor agar tidak salah persepsi dalam memaknai kegiatan supervisi pengajaran. Karena memang tujuan dan manfaat nya adalah untuk memberdayakan guru secara profesional dalam melaksanakan tanggung jawabnya sebagai tenaga pendidik, sehingga kinerja guru dalam proses belajar mengajar dapat optimal dan berkualitas. Sehingga diharapkan dari meningkatnya mutu pendidikan yang ada di sebuah Lembaga pendidikan dapat menghasilkan output yang baik pula. Inilah kenapa Pondok Modern Darussalam Gontor kampus 10 Tanjabtim Jambi selalu mengadakan kegiatan supervisi pengajaran setiap minggunya, selain untuk meningkatkan guru juga karena kualitas pendidikan dan pengajaran yang baik akan berdampak positif bagi kepercayaan masyarakat dalam menyekolahkan anaknya. 


\section{METODOLOGI PENELITIAN}

Penelitian ini menggunakan pendekatan kualitatif dengan metode deskriptif. Penelitian ini ditujukan untuk mendeskripsikan dan menganalisis fenomena, peristiwa, aktifitas sosial, sikap, kepercayaan, persepsi, dan pemikiran orang baik secara individual maupun secara kelompok. Hal ini juga telah disampaikan (Suryana, 2012) dan (Emzir, 2017) tentang metodologi penelitian kualitatif. Menurut (Dewi Rokhmah, Iken Nafikadini, 2009) Penelitian bisa saja dilakukan dalam situasi yang wajar melalui pengamatan terhadap orang dan lingkungan hidupnya. Peneliti turun ke lapangan, berinteraksi dengan mereka, berusaha memahami bahasa dan tafsiran mereka tentang dunia sekitarnya, mengadakan pengamatan dan penjelajahan. Lokasi dalam penelitian ini bertempat di Pondok Modern Darussalam Gontor Kampus 10 Jambi. Untuk mendapatkan informasi yang akurat maka penulis melakukan wawancara dengan dua orang supervisor, ini guna mendapatkan informasi terkait hasil dari supervisi, selain itu juga dengan lima orang guru sebagai sumber data inti untuk mengetahui persepsi masing-masing terhadap supervisi pengajaran. Adapun teknik pengumpulan datanya dengan observasi, wawancara dan dokumentasi. Kemudian data yang telah diperoleh dianalisis dengan cara display data, reduksi data dan yang terakhir konklusi data/kesimpulan.

\section{PEMBAHASAN DAN HASIL}

- Totalitas pendidikan ala Gontor dalam meningkatkan mutu pendidik dan pendidikan

Pondok Modern Darussalam Gontor selalu totalitas didalam mendidik para santrisantrinya. Para guru selalu berusaha untuk menjadi teladan yang baik bagi seluruh santri terkhusus dalam proses belajar mengajar. Keteladanan guru menurut (Syaepul Manan, 2017) ini tidak kalah pentingnya dengan proses belajar mengajar di dalam kelas, hal ini disebabkan proses pengetahuan atau tingkah laku yang diperoleh dari pembiasaan akan sangat sulit untuk mengubah dan menghilangkannya, maka dari itu keteladanan yang baik akan sangat berpengaruh pada pola pikir dan tingkah laku anak dikemudian hari. Menurut (Mochtar, 2019) secara historis pesantren telah ada di Indonesia sejak lama dan menjadi bagian terpenting dalam melawan penjajahan. Menurut (Usman, 2013) Pondok pesantren sebagai lembaga pendidikan yang memiliki akar kuat (indigenous) pada masyarakat muslim Indonesia, dalam perjalanannya mampu menjaga dan mempertahankan keberlangsungan dirinya (survival system) serta memiliki model pendidikan multi aspek. Maka dari itu selama cara dalam mendidik itu diyakini kebenarannya dan tidak menyalahi syariat Islam maka akan diterapkan di pondok pesantren Gontor, maka muncullah ungkapan thariqoh tadris atau cara mengajar itu lebih penting dari pada materi itu sendiri, dan guru itu lebih penting dari pada thariqah tadris, akan tetapi ada satu hal yang lebih penting daripada itu semua, yaitu ruhul mudarris (jiwa seorang pengajar) itu lebih penting daripada guru itu sendiri, yang mana inilah yang akan menjadi faktor utama dan penentu keberhasilan seorang guru dalam mentransfer ilmu kepada peserta didik. Dari uraian ini dapat difahami bahwa Pondok Modern Darussalam Gontor tidak hanya terfokus dalam mendidik mental dan karakter santri, akan tetapi sangat konsen terhadap proses belajar mengajar didalam kelas. Ini terbukti dari selalu diadakannya kegiatan supervisi pengajaran terhadap guru yang tidak lain adalah untuk mengetahui 
kelemahan guru dalam mengajar serta penguasaan materi pelajaran sehingga dapat di tingkatkan dan dikembangkan. Yang hal ini belum tentu dilakukan oleh pondok pesantren pada umumnya.

- Pengertian guru dan peranannya

Guru adalah seorang pendidik yang profesional dengan tugas utama mendidik, mengajar, membimbing, mengarahkan, melatih, menilai dan mengadakan evaluasi terhadap peserta didik pada jenjang pendidikan tertentu, sesuai dengan PP Nomor 74 Tahun 2008. Peraturan Menteri Pendidikan Nasional Nomor 16 tahun 2007 serta Peraturan Peemerintah Nomor 74 Tahun 2008 tentang guru, yang mengamanatkan bahwa guru wajib memiliki kompetensi pedagogik, kompetensi kepribadian, kompetensi sosial, dan kompetensi profesional. (Megiati \& Pratiwi, 2021) menjelaskan bahwa Guru sebagai agen pengetahuan senantiasa dituntut untuk meningkatkan kualitas peserta didik seutuhnya sehingga mampu memiliki daya saing yang tinggi dalam persaingan global. Jadi kemana arah masa depan bangsa sebenarnya dapat dilihat seberapa sungguh-sungguhnya guru dalam menyiapkan para siswa yang notabene adalah agen perubahan. Maka pelaksanaan pendidikanpun harus sejalan dengan pendidikan yang ada di Indonesia. Yang mana tujuan nya menurut UU RI No. 20/2003 adalah mengembangkan kemampuan dan membentuk watak serta peradaban bangsa yang bermartabat dalam rangka mencerdaskan kehidupan bangsa, bertujuan untuk berkembangnya potensi peserta didik agar menjadi manusia yang beriman dan bertaqwa kepada Tuhan Yang Maha Esa, berakhlak mulia, berilmu, cakap, kreatif, mandiri dan menjadi warga negara yang demokratis, serta bertanggung jawab.

- Kompetensi guru sebagai pendidik profesional

Kompetensi pedagogik merupakan kemampuan dalam mengelola peserta didik, kompetensi kepribadian dan kompetensi sosial merupakan kemampuan pendidik sebagai bagian dari masyarakat, serta kompetensi profesional merupakan kemampuan guru dalam menguasai bidang ilmu pengetahuan, teknologi, dan seni budaya yang diampu sekurang-kurangnya meliputi penguasaan materi pelajaran secara luas dan mendalam sesuai dengan standar isi program satuan pendidikan, mata pelajaran dan kelompok mata pelajaran yang akan diampu. Menurut (Roemintoyo, 2017) tentang kualifikasi guru tertuang dalam UU No. 14 Tahun 2005 ini dirumuskan dalam Pasal 8 yang menegaskan bahwa guru wajib memiliki kualifikasi akademik, kompetensi sertifikat pendidik, sehat jasmani dan rohani, serta memiliki kemampuan untuk mewujudkan tujuan pendidikan nasional. Sedangkan yangdimaksud dengan kualifikasi akademik tersebut di jelaskan dalam Pasal 9 yang menjelaskan bahawa kualifikasi akademik sebagaimana dimaksud dalam Pasal 8 diperoleh melalui pendidikan tinggi program sarjana atau program diploma empat. Adapun yang dimaksud dengan kompetensi guru dijelaskan dalam Pasal 10 ayat (1) yaitu bahwa kompetensi guru sebagaimana dimaksud dalam Pasal 8 meliputi kompetensi pedagogik, kompetensi kepribadian, kompetensi sosial, dan kompetensi profesional yang diperoleh melalui pendidikan profesi. Selanjutnya sertifikat pendidik sebagaimana yang dimaksud dalam Pasal 8 diberikan kepada guru yang telah memenuhi persyaratan. Kompetensi-kompetensi yang telah dijabarkan diatas akan menjadi bias bilamana tidak ada kesungguhan guru dalam 
menerapkan semua kompetensinya dengan niat yang tulus untuk mendidik muridnya agar menghasilkan output yang baik dan juga memiliki kepribadian dan karakter baik pula.

Selain daripada itu menjadi seorang guru profesional dan berdedikasi adalah sebuah keharusan dan juga sekaligus panggilan jiwa. Dimana saat ini kita dapat melihat tantangan perkembangan ilmu dan teknologi di era disrupsi, terus belajar pada hal-hal baru, memperdalam pengetahuan, meluaskan fikiran terhadap segala perkembangan yang baru adalah sikap profesional agar proses pembelajaran dan pendidikan bergulir kearah yang lebih baik dan sesui tujuan pendidikan yang telah dicanangkan. Pengembangan keprofesionalan secara berkelanjutan (continuous professional development) merupakan kesadaran dan tanggung jawab guru sebagai profesi. Menurut (Wahyuddin \& Ismayanti, 2020) Guru mengambil porsi paling besar dalam proses pendidikan anak dibandingkan dengan aktor pendidikan lainnya seperti kepala sekolah, orang tua, dan stakeholder. Menurut (Roemintoyo, 2017) Peningkatan dan pengembangan kemampauan profesional tersebut meliputi berbagai aspek antara lain kemampuan guru dalam menguasai kurikulum dan materi pengajaran, kemampuan dalam menggunakan metode dan sarana dalam proses belajar-mengajar, melaksanakan penilaian proses dan hasil belajar, dan kemampuan memanfaatkan lingkungan sebagai sumber belajar, disiplin dan komitmen guru terhadap tugas. Maka seorang guru profesional selain menguasai kompetensi-kompetensi dasar juga harus mampu merubah paradigma lama mengenai proses belajar mengajar, semisal merubah cara belajar pasif menjadi belajar aktif, yang sebelumnya informasi sepihak menjadi pertukaran informasi, dari respon reaktif menuju proaktif dan tindakan terukur dan terencana. Dan yang terpenting dari itu semua adalah Thariqoh tadris atau cara mengajar itu lebih penting dari pada materi itu sendiri, dan guru itu lebih penting dari pada Thariqah tadris, akan tetapi ada satu hal yang lebih penting daripada itu semua, yaitu Ruhul Mudarris (jiwa seorang pengajar) yang mana inilah yang akan menjadi faktor utama dan penentu keberhasilan seorang guru dalam mentransfer ilmu kepada peserta didik.

- Peningkatan mutu pendidikan lewat supervisi pengajaran

Tuntutan yang demikian itu hanya dapat dijawab oleh seorang guru yang profesional, yang dengan kompetensi profesional tersebut juga akan berpengaruh pada proses pengelolaan pendidikan sehingga guru tadi dapat melahirkan peserta didik yang bermutu dan berkualitas. Dalam penelitiannya (Wahyuddin \& Ismayanti, 2020) menyatakan bahwa banyak penelitian mengonfirmasi bahwa guru yang berkualitas akan memberikan dampak positif bagi anak. Sebagai contoh, guru efektif akan menghasilkan murid dengan tingkat kehadiran yang lebih tinggi. Dari proses pelaksanaan tugas-tugas diatas maka guru perlu dibimbing dan dilatih oleh kepala madrasah atau sekolah maupun juga pengawas eksternal yang sudah kompeten dibidangnya, melalui supervisi pengajaran (akademik) ataupun pelatihan-pelatihan keprofesionalan guru. Menurut (Megiati \& Pratiwi, 2021) bahwa supervisi sesungguhnya dibutuhkan untuk meningkatkan skill atau kemampuan terkait dengan penyelenggaraan pembelajaran di kelas, kemampuan melakukan penilaian, kemampuan melakukan koordinasi dengan guru lain, kemampuan memahami hubungan 
berbagai aktivitas di sekolah, kemampuan membuat perencanaan fungsi sekolah, kemampuan mengambil putusan tentang sesuatu yang berkaitan dengan karir, kemampuan melakukan pengembangan layanan evaluasi, kemampuan menentukan intervensi kelas pembelajaran, dan terakhir adalah kemampuan menghandel sesuatu sesuai dengan konteksnya yang bervariasi.

Maka kalau merujuk pada Permenpan dan Birokrasi No.21 tahun 2010, menyatakan dengan jelas bahwa dalam kedudukan dan fungsinya, pengawas adalah penanggung jawab utama atas terjadinya pembinaan madrasah sesuai dengan jenis dan jenjang lembaganya. Menurut (Setiono, 2017) bahwa didalam melaksanakan supervisi pengajaran kepala sekolah dan madrasah harus mengikuti tahapan-tahapan yang ada, Tahap perencanaan awal, pelaksanaan observasi, dan tahap akhir (diskusi balikan). Teknik-teknik supervisi pengajaran yang digunakan oleh kepala sekolah adalah: 1) Teknik supervisi individu, 2) Teknik kelompok, 3) Supervisi klinis. Tindak Lanjut hasil supervisi kepala sekolah adalah melakukan pembinaan dan mengevaluasi berdasarkan catatan-catatan hasil kunjungan kelas terhadap guru setiap tahun, dan membuat program pembinaan guru pada tahun berikutnya. Menurut (Etek, 2008) Supervisi berhubungan erat dengan kegiatan pengajaran, namun tidak berhubungan langsung dengan murid, kegiatan ini berfungsi untuk kelancaran pelaksanaan proses belajar mengajar di sekolah untuk mencapai tujuan hasil yang lebih baik selain itu supervisi pengajaran bertujuan untuk mengadakan pemeliharaan dan perbaikan pelaksanaan proses belajar mengajar. Maka dapat di fahami bersama bahwa kepala sekolah/madrasah dan pengawas dalam konteks ini bertanggung jawab dalam pelaksaan supervisi sehingga mampu membimbing dan meningkatkan kompetensi guru dalam menjalankan tugas profesinya. Maka dari penjelasan diatas, dapat diambil kesimpulan bahwa bimbingan ataupun pelayanan yang diberikan seorang pengawas dikenal dengan istilah supervisi pengajaran. Hal ini seperti yang telah di programkan didalam sistem pendidikan nasional yang mana adanya pengawas sekolah dan madrasah adalah sebagai supervisor dan juga evaluator. Akan tetapi karena urgensinya sangat tinggi maka jabatan ini membutuhkan kemampuan profesional yang sangat tinggi alias tidak sembarang orang, guru dapat menduduki jabatan tersebut.

- Persepsi guru mengenai supervisi pengajaran

Dari seluruh pembahasan dan penelitian terhadap persepsi guru dalam supervisi pengajaran yang ada di Pondok Modern Darussalam Gontor Kampus 10 Tanjabtim Jambi didapatkan hasil sebagai berikut:

1) Guru dengan persepsi positif

Dalam proses supervisi pengajaran yang telah dilakukan oleh seorang supervisor, guru yang mempunyai persiapan mengajar, mulai dari penulisan RPS, penguasaan materi, disiplin waktu kehadiran di kelas, cenderung lebih tenang dan berfikir bahwa apa yang diajarkan kepada santri sudah sesuai dengan SOP yang ada, materi yang disampaikanpun sudah dikuasai, maka akan bersikap bahwa kegiatan supervisi itu akan lebih meningkatkan dan mengembangkan cara mengajar, sehingga dapat menghasilkan output yang baik. 
2) Guru dengan persepsi negative

Kebalikan dari guru yang memiliki persepsi positif, guru ini cenderung lebih was-was, karena kurangnya kemampuan dalam memahami materi, atau pemahaman masih setengahsetengah, tidak ada persiapan mengajar, maka ketika sedang di supervisi pasti tidak nyaman, merasa terganggu, tidak bebas dalam mengajar, yang akhirnya bingung apa yang akan disampaikan, pada akhirnya akan menimbulkan persepsi negative dalam dirinya terhadap kegiatan supervisi.

3) Guru yang bersikap biasa-biasa saja

Model seperti ini biasanya guru yang sudah lebih berpengalaman karena sudah sering disupervisi sehingga tahu bagaimana bersikap. Sikap ini bisa didasari karena persiapan sudah matang, dan menguasai materi yang akan diajarkan.

\section{KESIMPULAN DAN SARAN}

Dari seluruh uraian hasil penelitian dan pembahasan tentang persepsi guru terhadap supervisi pengajaran yang telah dilakukan di Pondok Modern darussalam Gontor kampus 10 Jambi, maka dapat disimpulkan sebagai berikut:

- Guru dituntut untuk lebih extra dalam menjalankan tugas pokok dan fungsinya sehingga tercipta mutu pendidikan yang baik.

- Guru harus memiliki kompetensi-kompetensi dasar, sehingga mampu menjadi sosok pendidik yang mengajar sepenuh jiwa bukan hanya sekedar menyampaikan materi.

- Thariqoh tadris atau cara mengajar itu lebih penting dari pada materi itu sendiri, dan guru itu lebih penting dari pada Thariqah tadris, akan tetapi ada satu hal yang lebih penting daripada itu semua, yaitu Ruhul Mudarris (jiwa seorang pengajar) itu lebih penting daripada guru itu sendiri, yang mana inilah yang akan menjadi faktor utama dan penentu keberhasilan seorang guru dalam mentransfer ilmu kepada peserta didik.

- Beragam persepsi guru terhadap supervisi pengajaran ternyata dilatar belakangi dari kesiapan guru didalam menjalankan tugasnya, yang diantaranya dari segi penguasaan materi, cara penyampaian, maupun disiplin guru itu sendiri.

Dari sini diharapkan terlahir guru yang profesional dan sanggup menjawab tantangan perkembangan zaman, sehingga dapat menghadirkan perubahan dalam peta pendidikan di Indonesia menuju ke arah yang lebih baik sekaligus menjadikan Islam yang rahmatan lil 'alamin.

\section{DAFTAR PUSTAKA}

Aedi, N. (2014). Pengawasan Pendidikan: Tinjauan Teori dan Praktik. In Jakarta: Rajawali Pers.

Amin, H. (2016). PEMBAHARUAN SISTEM PENDIDIKAN ISLAM DI PESANTREN. Raudhah Proud To Be Professionals : Jurnal Tarbiyah Islamiyah, 1(1). https://doi.org/10.48094/raudhah.v1i1.5

Budiman, A., Harun, C., \& Usman, N. (2015). Pelaksanaan Supervisi Pengajaran Oleh Kepala Sekolah Dalam Meningkatkan Kemampuan Mengajar Guru Pada SMA Negeri I Seunagan 
Kabupaten Nagan Raya. Intelektualita, 3(2).

Burhanuddin, M. (2017). THE ROLES OF PRINCIPALS IN INCREASING EDUCATION QUALITY BY DEVELOPING TEACHER PROFESIONALISM. Didaktika Religia, 5(1), 143-174. https://doi.org/10.30762/didaktika.v5i1.616

Dewi Rokhmah, Iken Nafikadini, E. I. (2009). Penelitian Kualitatif. In Journal Equilibrium: Vol. 5 No. 9 (Issue 127).

Djailani, D. (2012). PENINGKATAN KOMPETENSI GURU MTsN KOTA BANDA ACEH MELALUI SUPERVISI PENGAJARAN. Jurnal Ilmiah Didaktika, 12(2). https://doi.org/10.22373/jid.v12i2.456

Emzir. (2017). Metodologi penelitian pendidikan kuantitatif \& kualitatif. In Metodologi penelitian pendidikan kuantitatif \& kualitatif.

Etek, Y. (2008). Supervisi Akademik dan Evaluasi Pengajaran. Cet. II, h. 13.

Gunawan, I. (2015). Mengembangkan Alternatif-Alternatif Pendekatan Dalam Pelaksanaan Supervisi Pengajaran. Manajemen Pendidikan, 24(6).

Maya putri, M. (2016). PELAKSANAAN SUPERVISI PENGAJARAN DALAM MENINGKATKAN PROSES BELAJAR MENGAJARDI SMA NEGERI 5 KOTA BANDA ACEH. Jurnal Administrasi Pendidikan : Program Pascasarjana Unsyiah, 4(3).

Megiati, Y. E., \& Pratiwi, N. K. (2021). Persepsi Guru atas Supervisi Kepemimpinan Kepala Madrasah terhadap Kinerja Guru. SAP (Susunan Artikel Pendidikan), 6(1). https://doi.org/10.30998/sap.v6i1.9357

Mochtar, A. (2019). POLA DAN MODEL PERUBAHAN PESANTREN. Eduprof : Islamic Education Journal, 1(1). https://doi.org/10.47453/eduprof.v1i1.13

Niswanto., N. (2016). SUPERVISI PENGAJARAN OLEH KEPALA SEKOLAH UNTUK MENINGKATKAN KOMPETENSI PEDAGOGIK GURU PADA SMA TARBIYAH LABUHAN HAJI ACEH SELATAN. Jurnal Administrasi Pendidikan : Program Pascasarjana Unsyiah, 4(4).

Suryana, Ms. (2012). Metodologi Penelitian : Metodologi Penelitian Model Prakatis Penelitian Kuantitatif dan Kualitatif. Universitas Pendidikan Indonesia. https://doi.org/10.1007/s13398-014-0173-7.2

Roemintoyo, R. (2017). SUPERVISI PENGAJARAN UNTUK MENINGKATKAN PROFESIONALISME GURU DI SEKOLAH DASAR (Studi Multikasus di SD Laboratorium Sumber Ilmu,SDN Sekar Arum I, SDK Sang Surya, San SON Madukoro VI, Malang). Jurnal Ilmiah Pendidikan Teknik Dan Kejuruan, 6(2). https://doi.org/10.20961/jiptek.v6i1.12518

Rugaiyah, R. (2016). PENGEMBANGAN MODEL SUPERVISI KLINIS BERBASIS INFORMASI DAN TEKNOLOGI. Jurnal Cakrawala Pendidikan, 35(3). https://doi.org/10.21831/cp.v35i3.10429

Setiono. (2017). Analisis Terhadap Kompetensi Kepala Sekolah Dalam Supervisi Dan Evaluasi Sesuai Dengan Peraturan Pemerintah (Terbaru). As-Salam: Jurnal Studi Hukum Islam \& Pendidikan, 6(2).

Suklani, S., \& Wahyudi, E. (2012). HUBUNGAN SUPERVISI GURU DENGAN KOMPETENSI PENGAJARAN MATEMATIKA DI MGMP SMP MATEMATIKA RAYON 1 KOTA CIREBON. Eduma : Mathematics Education Learning and Teaching, 1(2). https://doi.org/10.24235/eduma.v1i2.303

Supriadi, B. (2019). Hakikat Supervisi Dalam Pendidikan Islam. Indonesian Journal of Islamic Educational Management, 2(1), 1. https://doi.org/10.24014/ijiem.v2i1.7120 
Syaepul Manan. (2017). Pembinaan Akhlak Mulia Melalui Keteladanan dan Pembiasaan. Jurnal Pendidikan Agama Islam-Ta'lim, XV(2), 1.

Ubabuddin. (2019). MENINGKATKAN KINERJA GURU MELALUI SUPERVISI PEMBELAJARAN. Ed-Humanistics : Jurnal Ilmu Pendidikan, 4(1).

https://doi.org/10.33752/ed-humanistics.v4i1.366

Usman, M. I. (2013). Pesantren Sebagai Lembaga Pendidikan Islam (Sejarah Lahir, Sistem Pendidikan, Dan Perkembangannya Masa Kini). Jurnal Al-Hikmah, 14(1).

Wahyuddin, W., \& Ismayanti, M. (2020). PERSEPSI GURU MENGENAI GURU IDEAL. JURNAL NALAR PENDIDIKAN, 8(2), 104. https://doi.org/10.26858/jnp.v8i2.15258 